\title{
Video-assisted surgery via periareolar, mitral valve replacement and papillary muscle relocation with neochordae of PTFE
}

\author{
LM Abreu, MLM Alves, J Honório, DC Ferreira, PN Sampaio, D Bastos, A Bosiger, S Godoy, DC Ferreira, \\ O Souza Neto*
}

From 23rd World Congress of the World Society of Cardio-Thoracic Surgeons Split, Croatia. 12-15 September 2013

\section{Background}

Cardiac surgery is looking for new techniques, which are less traumatic with better cosmetic and functional results. The minimally invasive mitral valve in the first procedure is rapidly becoming standard access in several centers around the word. The objective of this report is to show that this new technique can lead to an improved quality of life after surgery and therefore a quicker return to everyday life.

\section{Methods}

MFS, 42-year-old female, with history of rheumatic process in childhood. Referred to cardiac surgery in New York Heart Association (NYHA) functional class III and indications of surgical treatment of mitral valve. Reached the right hemi thorax through the 4th right intercostals' space (RICS) in the nipple-areolar complex after ventilation of the left lung. In the same intercostals' space, anterior to the axillary middle line, was introduced a $7 \mathrm{~mm}$ optical trocar to $30^{\circ}$. At 7 th RICS in the anterior axillary line (AAL), we implemented a trocar $7 \mathrm{~mm}$ which was introduced for insufflation of $\mathrm{CO} 2$ and introduction of the soft aspirator. cardiopulmonary bypass $(\mathrm{CPB})$ was established via femoral. In order to maintain ventricular geometry were implanted neochordae PTFE Teflon anchored in the region fibrotic papillary muscle and attached to the mitral annulus in the direction of A1 and A2. The biologic prosthesis ${ }^{\circ} 29$ was implanted with points with braided polyester Teflon in a "U".

* Correspondence: osouzaneto@globo.com

Department of Cardiovascular Surgery, Hospital Federal dos Servidores, Rio de Janeiro, Brazil

\section{Results}

The procedure was successfully performed. The CPB time was 110 minutes $(\mathrm{min})$ and aortic clamping of $95 \mathrm{~min}$. The period of mechanical ventilation was 8 hours, bleeding postoperatively of $190 \mathrm{ml}$. In 36 hours the patient was discharged.

\section{Conclusion}

Minimally invasive surgery video assisted with periareolar approach for treatment of mitral valve with papillary muscle repositioning is technique with potential to reduce the recovery time with the advantages of a less invasive procedure for the patient.

Published: 11 September 2013

doi:10.1186/1749-8090-8-S1-P144

Cite this article as: Abreu et al:: Video-assisted surgery via periareolar, mitral valve replacement and papillary muscle relocation with neochordae of PTFE. Journal of Cardiothoracic Surgery 2013 8(Suppl 1):P144.

Submit your next manuscript to BioMed Central and take full advantage of:

- Convenient online submission

- Thorough peer review

- No space constraints or color figure charges

- Immediate publication on acceptance

- Inclusion in PubMed, CAS, Scopus and Google Scholar

- Research which is freely available for redistribution 